\title{
Lipid profile level in oral cancer and its significance on histological grade
}

\author{
Mallik $\mathbf{M}^{1}$, Mallick $S^{2}$, Kumar $\mathbf{M}^{3}$, Barier $\mathbf{N K}^{4}$ \\ ${ }^{1}$ Dr. Mahasweta Mallik, MBBS MD, Pathology, Assistant Professor, Patna Medical College, Bihar India, ${ }^{2}$ Dr. Sujata \\ Mallick, MBBS MD, Pathology, Assistant Professor, KPC Medical College, Jadavpur, ${ }^{3}$ Dr. Manish Kumar, MBBS MD, \\ Pathology, Assistant Professor, Patna Medical College, Bihar, ${ }^{4}$ Dr. Naveen Kumar Bariar, MBBS MD, Pathology, \\ Associate Professor, Patna Medical College, Bihar, India
}

Address for correspondence: Dr. Mahasweta Mallik, Email: coolsama6773@yahoo.co.in

\begin{abstract}
Introduction: Oral cancer is one of the commonest cancer in India. Its early detection can prevent morbidity and motality. Aim of this study is to estimate the lipid profile level in oral cancer and its significance on histopathological grade. Material and method: 70 patients with established oral squamous cell carcinoma were taken in the study and their lipid profile analysed. Result: lipid profile had an inverse relationship with oral cancer with no significant relation with histopathological grade. Conclusion: lipid profile estimation is a cost effective method to detect oral cancer.
\end{abstract}

Key Words: Lipid Profile, Oral Squamous cell Carcinoma.

\section{Introduction}

Oral cancer is the sixth most common cancer in the world [1]. According to cancer registry data in India it is the no. 1 cancer among men \& no. 3 among women. Early detection of cancer leads to improved treatment \& better prognosis [2]. Blood based tests are easy to perform, economical \& repeated samples can be tested [3]. Malignancy occurs due to uncontrolled proliferations of cells or decreased apoptosis [3]. Lipid is an essential component for the cell membrane, so the lipid level falls due to rapidly dividing cells $[4,5]$.

In the last few decades lipid levels \& coronary disease association has been established. Researchers have also observed an inverse relationship between serum lipid level \& cancer. Few studies have been done to find lipid level in carcinoma pharynx, carcinoma lungs, leukemia, breast cancer \& oral cancer. Squamous cell carcinoma is the most common oral cancer $\&$ has been categorized by Broder as well differentiated, moderately differentiated \& poorly differentiated. This study aims to see the lipid profile in the oral cancer mainly squamous cell carcinoma \& its significant with different histological grade.

Manuscript received $12^{\text {th }}$ March 2016

Reviewed: $24^{\text {th }}$ March 2016

Author Corrected: $4^{\text {th }}$ April 2016

Accepted for Publication $19^{\text {th }}$ April 2016

\section{Material and Method}

70 patients with of oral squamous cell carcinoma were studied in a Patna Medical College and Hospital. This was a prospective study. Known case of Hypertension, hypercholesterolemia and Diabetes mellites were excluded from the study. All the other patients who were histopathologically confirmed as oral Squamous cell carcinoma were included in the study. The patients were categorized into well differentiated, moderately differentiated and poorly differentiated squamous cell carcinoma. Written informed consent was taken from these patients. Blood samples of these patients were taken and their serum lipid profile was done by Merck semi autoanalyser using reagent from Merck. Cholesterol was calculated by enzymatic colorimetric method (end point reaction) by taking $1.0 \mathrm{~mL} \mathrm{R} 1$ monoreagent to it $10 \mathrm{uL}$ sample taken. In another test tube $1.0 \mathrm{~mL} \mathrm{R} 1$ monoreagent and $10 \mathrm{uL}$ standard taken.samples mixed and incubated for 5 minutes at $37^{\circ} \mathrm{C}$. Samples read at $500 \mathrm{~nm}$ in absorbance mode.

Triglyceride was also calculated just like cholesterol with triglyceride monoreagent and triglyceride standard. HDL was calculated by the following method. $0.5 \mathrm{ml}$ serum added with $0.5 \mathrm{ml}$ HDL precipitating reagent and centrifused at 4000 r.p.m for 10 minutes. Then $0.05 \mathrm{ml}$ 
supernatant is taken and $1.0 \mathrm{ml}$ cholesterol working enzyme added. In another test tube $0.05 \mathrm{ml}$ standard and $1.0 \mathrm{ml}$ cholesterol working enzyme added. This was incubated for 10 minutes at $37^{\circ} \mathrm{C}$ and absorbance is measured at 510nm.
Calculation- HDL-Choleserol in $\mathrm{mg} \%=$ Absorbance of sample/absorbance of standard $* 100$

VLDL and LDL were calculated using the following formula. VLDL=TG/5 LDL=TC-VLDL-LDL

\section{Result}

Out of the 70 cases 42 were male and 27 were female. Age range was from 24years to 72 years with mean age of 52 years. All the cases had history of tobacco intake either in form of quid or smoking. Out of the 70 cases: 28 were well differentiated; 26 moderately differentiated and 16 poorly differentiated Squamous cell carcinoma.

Table 1: Showing lipid profile in different grades of cancer.

\begin{tabular}{|l|l|l|l|l|l|l|}
\hline Type & $\begin{array}{l}\text { No of } \\
\text { cases }\end{array}$ & $\begin{array}{l}\text { Total } \\
\text { Cholesterol(TC) }\end{array}$ & $\begin{array}{l}\text { High density } \\
\text { lipoprotein(HDL) }\end{array}$ & $\begin{array}{l}\text { Low density } \\
\text { lipoprotein(LDL) }\end{array}$ & $\begin{array}{l}\text { Very low density } \\
\text { lipoprotein(VLDL) }\end{array}$ & $\begin{array}{l}\text { Triglyceride } \\
\text { (TG) }\end{array}$ \\
\hline W.D & 28 & $138.2 \pm 10.28$ & $26.01 \pm 4.16$ & $85.35 \pm 14.16$ & $15.21 \pm 7.95$ & $79.16 \pm 12.12$ \\
\hline M.D & 26 & $129.3 \pm 6.25$ & $27.31 \pm 2.71$ & $78.42 \pm 12.24$ & $16.16 \pm 3.31$ & $78.15 \pm 13.17$ \\
\hline P.D. & 16 & $122.0 \pm 8.29$ & $24.23 \pm 3.95$ & $80.36 \pm 8.71$ & $18.28 \pm 5.12$ & $80.34 \pm 14.21$ \\
\hline
\end{tabular}

W.D=Well Differentated, M.D.=Moderately Differentiated, P.D.=Poorly Differentiated.

\section{Discussion}

Oral cancer is the commonest cancer among males in India due to the habit of taking tobacco in the form of quid and smoke. Most common among oral cancer is squamous cell carcinoma. Our study also had a male preponderance similar to study by Singh S et al[9] and Kumar P et al[3]. Oral cancer occurs mainly in older age group. Our study had a mean age of 52 years similar to Singh S (51.07years), Kumar P $\left(4^{\text {th }}\right.$ to $5^{\text {th }}$ decade)[3,9]. Our study showed lowering of all the lipid parameters. This lowering was not according to the grade of cancer.

Table 2 : Showing comparative analysis of lipid profile by different writers.

\begin{tabular}{|l|l|l|l|l|l|l|l|l|l|}
\hline \multirow{2}{*}{ Lipid profile } & \multicolumn{4}{|l|}{ Singh et al [9] } & \multicolumn{3}{l|}{ Kumar et al [3] } & \multicolumn{2}{l|}{ Present } \\
\cline { 2 - 11 } & W.D & M.D & P.D. & W.D. & M.D. & P.D. & W.D. & M.D. & P.D \\
\hline Total cholesterol & 175.64 & 179.93 & 179.00 & 131.43 & 116.51 & 114.00 & 138.2 & 129.3 & 122.0 \\
\hline HDL & 40.43 & 41.63 & 38.78 & 31.12 & 31.54 & 25.35 & 26.01 & 27.31 & 24.23 \\
\hline LDLC & 127.21 & 113.37 & 112.11 & 109.36 & 105.57 & 111.0 & 85.35 & 78.42 & 80.36 \\
\hline VLDL & 23.86 & 23.41 & 22.11 & 27.02 & 17.91 & 24.1 & 15.21 & 16.16 & 18.28 \\
\hline TG & 102.50 & 101.96 & 94.56 & 116.67 & 99.14 & 121.5 & 79.16 & 78.15 & 80.34 \\
\hline
\end{tabular}

W.D.=Well Differentiated, M.D.=Moderately Differentiated, P.D.=Poorly differentiated. HDL-High Density Lipoprotein, LDLC-Low density lipoprotein, VLDL-Very low Density Lipoprotein, TG-Triglyceride.

Singh $\mathrm{S}$ et al also showed lower lipid profile levels [9]. Kumar $\mathrm{P}$ also showed inverse relationship of lipid profile with carcinoma [3]. But Bailward showed triglyceride level to be variable, HDL lowered, LDL and VLDL levels were non significant [10]. Kumar P et al and Singh et al showed lowered lipid level which had no correlation with grading[3][9]. This was similar to the present study. Rose et al showed $66 \%$ high mortality rate in cancer with low cholesterol [7]. This fall in lipid profile may be due to the rapidly proliferating cancer cells which need lipid for its cell membrane. Another theory is that tobacco, which contains nicotine is a proven carcinogenic agent in animal studies, causes production of free radical and reactive oxygen species that cause peroxidation of polyunsaturated fatty acid(PUFA) leading to carcinogenesis,thus fall in lipid level[11, 12]. Cholesterol and triglyceride are important constituents of cell and carries out many important physiological functions. Cholesterol maintains the structure and function of cell membrane. It also helps in activity of membrane bound enzyme and also stabilizes DNA helix [13]. Cholesterol is in our tissue and plasma 
as free cholesterol or in combination with long chain fatty acid, as cholesterol ester. Cholesterol is the precursor of mainly steroids in our body example corticosteroid, sex hormone, bile acid and vitamin D. Cholesterol is an constituent of lipoprotein fraction like LDL,HDL and VLDL.

Cholesterol is amphipathic lipid and an essential structure component of membrane and plasma lipoprotein. Lipoprotein transports free cholesterol and readily equilibrates with cholesterol in membranes. Storage form of cholesterol is cholesterol ester. LDL is the mediator of cholesterol and cholesterol ester uptake in many tissue [14].

In cancer, blood cholesterol undergoes early and significant change. This change is due to cancer or its effect is not known. Some studies have shown that tumor cells have direct lipid lowering effect or there is some secondary dysfunction of lipid metabolism or secondary to antioxidant vitamin.[15,16,17]. Previous reports have shown that low HDL is a predictor of cancer $[18,19,20]$ and this may be due to increase utilization of cholesterol for membrane biosynthesis.

Double bond fatty acid are susceptible to oxidation. Fatty oxidation converts fatty acid to hydroperoxides which decompose to form ketoacid and hydroxyketoacid. This causes destruction of fat soluble vitamins in food. Oxidative damage also occurs in membrane phospholipid damaging cell membrane and also membrane protein. Lipid peroxidation occurs by hydrogen peroxide which is formed by Haber Weiss reaction or Fenton reaction [21].

Tobacco carcinogens produces reactive oxygen species which causes lipid damage and generates lipid peroxides [9]. This process affect essential constituents of cell membranes and may result in tumorigenesis.[22][23].

Vitamin $\mathrm{E}$ is co-transported with cholesterol and prevent lipid peroxidation.[24]. It has been observed that fat soluble antioxidant vitamin such as vitamin $\mathrm{E}$ and beta carotene decreases in tobacco users[25] as fatty acid oxidation destroys fat soluble vitamin. So there is a decrease in plasma level of total cholesterol, HDL, LDL, VLDL and Triglyceride.

So the fall in lipid can be a cause or a result of cancer is still debatable.

\section{Conclusion}

In our condition where poverty is high and oral cancer continues to rise, lipid profile estimation can be easy, affordable method to detect cancer early. This avenue needs to researched further so as to find the cause of fall in serum lipid level which can be a cause leading to carcinogenesis or a result of cancer.

Funding: Nil, Conflict of interest: None initiated. Permission from IRB: Yes

\section{Reference}

1. Day TA, Davis BK, Gillespie MB, Joe JK, Kibbey M, Martin-Harris B, Neville B, Richardson MS, Rosenzweig S, Sharma AK, Smith MM, Stewart S, Stuart RK. Oral cancer treatment. Curr Treat Options Oncol. 2003 Feb;4(1):27-41.

2. NIH fact sheets. Oral Cancer.Assessed at :http://report.nih.gov/nihfactssheets/viewfactsheet.aspx? csid=106.

3. Kumar P, Augustine J, Urs AB, Arora S, Gupta S, Mohanty VR. Serum lipid profile in oral cancer and leukoplakia: correlation with tobacco abuse and histological grading. J Cancer Res Ther. 2012 JulSep;8(3):384-8. doi: 10.4103/0973-1482.103517.

4. Cheng B, Rhodus NL, Williams B, Griffin RJ. Detection of apoptotic cells in whole saliva of patients with oral premalignant and malignant lesions: a preliminary study. Oral Surg Oral Med Oral Pathol Oral Radiol Endod. 2004 Apr;97(4):465-70.

5. Gupta S, Gupta S. Indian J of dentistry Alteration in serum lipid. Profile patterns in oral cancer and oral precancerous lesions and conditions-a clinical study.2011;2(2):1-7.

6. Schatzkin A, Hoover RN, Taylor PR, et al. Cancer Res. Site-specific analysis of total serum cholesterol and incident cancer in the National Health and Nutrition Examination Survey I Epidemiologic Follow-up Study.1988 Jan 15;48(2):452-8.

7. Rose G, Shipley MJ. Plasma lipids and mortality: a source of error. Lancet. 1980 Mar 8;1(8167):523-6.

8. Gilbert HS, Ginsberg H, Fagerstrom R, Brown WV. Characterization of hypocholesterolemia in myeloproliferative disease. Relation to disease 
manifestations and activity. Am J Med. 1981 Oct; 71(4):595-602

9.Singh S, Ramesh V, Premalatha B, Prashad KV, Ramadoss K. Alterations in serum lipid profile patterns in oral cancer. J Nat Sci Biol Med. 2013 Jul;4(2):374-8. doi: 10.4103/0976-9668.116994.

10. Bailwad SA, Singh N, Jani DR, Patil P, Singh M, Deep G, Singh SAlterations in serum lipid profile patterns in oral cancer: correlation with histological grading and tobacco abuse. Oral Health Dent Manag. 2014 Sep;13(3):573-9.

11. Sherubin EJ, Khannan KS, Kumar DN et al J Oral Maxillofac pathol. Estimation of plasma lipids and its significance on histopathological grades in oral cancer. Prognostic significance an original research. 2013: 17:4-9.

12. Patel PS, Shah MH, Jha FP, Raval GN, Rawal RM, Patel MM, Patel JB, Patel DD. Alterations in plasma lipid profile patterns in head and neck cancer and oral precancerous conditions. Indian J Cancer. 2004 JanMar;41(1):25-31.

13. Sabine JR, Cholesterol, New York;1977.

14. Peter A. Mayer, Harper's Biochemistry, 2000 edition, p-285,Appleton and Lange Publication.

15. Eichholzer M, Stähelin HB, Gutzwiller F, Lüdin E, Bernasconi F. Association of low plasma cholesterol with mortality for cancer at various sites in men: 17-y follow-up of the prospective Basel study. Am J Clin Nutr. 2000 Feb;71(2):569-74.

16. Feinleib M. Review of the epidemiological evidence for a possible relationship between hypocholesterolemia and cancer. Cancer Res. 1983 May;43(5 Suppl):2503s$2507 \mathrm{~s}$.
17. Peto R, Doll R, Buckley JD, Sporn MB. Can dietary beta-carotene materially reduce human cancer rates? Nature. 1981 Mar 19;290(5803):201-8.

18. Halton JM, Nazir DJ, McQueen MJ, Barr RD. Blood lipid profiles in children with acute lymphoblastic leukemia. Cancer. 1998 Jul 15; 83(2):379-84.

19. Budd D, Ginsberg H. Cancers. Hypocholesterolemia in Acute myelogenous leukemia. Association between disease activity and plasma low density lipoprotein cholesterol concentrations 1986;58:1361-5.

20. Dessi S, Batetta B, Pulisci D, Spano O, Cherchi R, Lanfranco G, Tessitore L, Costelli P, Baccino FM, Anchisi C, et al. Altered pattern of lipid metabolism in patients with lung cancer. Oncology. 1992;49(6):43641.

21. Saini AS. Text book of biochemistry. $2^{\text {nd }}$ edition, 1995, CBS Publisers, New Delhi.

22. Lohe VK, Degwekar SS, Bhowate RR, Kadu RP, Dangore SB. Evaluation of correlation of serum lipid profile in patients with oral cancer and precancer and its association with tobacco abuse. J Oral Pathol Med. 2010 Feb;39(2):141-8. doi: 10.1111/j.1600-0714. 2009. 00828.x. Epub 2009 Dec 7.

23. Ames BN. Dietary carcinogens and anticarcinogens. Oxygen radicals and degenerative diseases. Science. 1983 Sep 23;221(4617):1256-64.

24. Choi MA, Kim BS, Yu R. Serum antioxidative vitamin levels and lipid peroxidation in gastric carcinoma patients. Cancer Lett. 1999 Feb 8;136(1):8993.

25. Raval GN, Patel DD, Sainger RN, Shah MH, Shah JS, Patel MM, et al. Asian Pacific J Cancer Prev. A study of various sociodemographic factors and plasma vitamin levels in oral and pharyngeal cancer in Gujarat, India. 2001;2:215-24.

\section{How to cite this article?}

Mallik M, Mallick S, Kumar M, Barier NK. Lipid profile level in oral cancer and its significance on histological grade. Int J Med Res Rev 2016;4(5):713-716.doi: 10.17511/ijmrr.2016.i05.08. 